\title{
Efficiency of three halophyte species in removing nutrients from saline water: a pilot study
}

\author{
H. J. De Lange • M. P. C. P. Paulissen
}

Received: 3 July 2015/Accepted: 30 March 2016/Published online: 13 April 2016

(C) The Author(s) 2016. This article is published with open access at Springerlink.com

\begin{abstract}
Saline wetlands may be well suited for purifying contaminated water from saline agriculture and aquaculture or from freshwater-based agriculture in areas subject to increased salinity. However, case studies on the nutrient removal efficiency of halophyte species are scarce, especially for temperate regions. Here we tested the nutrient removal efficiency and ability to store nutrients in aboveground and belowground biomass of three halophyte species, Aster tripolium, Bolboschoenus maritimus subsp. compactus, and Spartina anglica, in a greenhouse microcosm experiment at two salinity levels. Nutrient removal from water differed among the species: Spartina had the highest nitrogen removal, Bolboschoenus and Spartina had the highest phosphorus removal. The species also differed in the allocation of the nutrient uptake. Bolboschoenus had the highest absolute uptake of nitrogen and phosphorus in shoots, whereas Spartina had the highest uptake of nitrogen and phosphorus in roots. The applicability of these three species in constructed saline wetlands depends on the local salinity and water regime.
\end{abstract}

Electronic supplementary material The online version of this article (doi:10.1007/s11273-016-9489-8) contains supplementary material, which is available to authorized users.

H. J. De Lange $(\bowtie) \cdot$ M. P. C. P. Paulissen

Alterra, Wageningen UR, PO Box 47, 6700 Wageningen,

The Netherlands

e-mail: marieke.delange@wur.nl
Keywords Aster tripolium $\cdot$ Bolboschoenus maritimus subsp. compactus - Spartina anglica . Nutrient removal efficiency · Plant uptake · Constructed wetland $\cdot$ Salt marsh

\section{Introduction}

Many constructed wetlands are designed to purify contaminated freshwater (e.g. Verhoeven and Meuleman 1999; Kadlec and Wallace 2009). Cases where the inflowing water is (highly) saline often originate from industrial sources and this water is typically also characterized by high concentrations of heavy metals or hydrocarbons (Kanagy et al. 2008; Calheiros et al. 2012; Carvalho et al. 2013; González-Alcaraz et al. 2013; Tao and Yu 2013). Our understanding of the ability of saline constructed wetlands to purify water from agricultural sources is mostly from traditional agricultural systems in arid regions (Lymbery et al. 2006), from aquaculture in (sub)tropical regions (Ye et al. 2001; Shpigel et al. 2013; Jesus et al. 2014), and the laboratory (Gregory et al. 2010, 2012). Larger scale field applications are available from tropical regions, and range from constructed recirculation aquaculture systems (Lin et al. 2010; Tilley et al. 2002) to natural systems (Gautier et al. 2001; Gennaro et al. 2006). Examples of full-scale constructed wetlands in temperate regions purifying contaminated saline water from aquaculture sources are only 
recently becoming available (e.g. Webb et al. 2012, 2013; Quintã et al. 2015a, b). Yet, saline wetlands may be well suited for purifying contaminated water from saline agriculture or from freshwater-based agriculture in areas subject to increased salinity (e.g. Buhmann and Papenbrock 2013; De Lange et al. 2013). Such saline constructed wetlands may help to prevent unwanted loading of vulnerable estuaries or coastal waters with nutrients, organic pollutants and/or pathogens from both point and diffuse sources. Salinity pressure is increasing in many low-lying coastal areas worldwide due to climate change and sea level rise (e.g. Rozema and Flowers 2008). In this perspective, saline treatment wetlands can be considered a logical and sustainable adaptation measure, with various additional advantages such as providing a semi-natural transition zone between intensively used agricultural areas and adjacent natural estuarine and coastal areas (Roncken et al. 2011). At the same time, the rehabilitation and/or enhancement of existing salt marshes will provide other essential ecosystem services, such as the stabilisation of fine sediments, providing a protective buffer between land and sea, and providing a habitat to a diversity of terrestrial and marine fauna (Laegdsgaard 2006).

The development of full-scale saline constructed wetlands is currently hampered, at least in the European context, by knowledge gaps about purification efficiencies of native salt-tolerant plants (e.g. Buhmann and Papenbrock 2013; De Lange et al. 2013). As reviewed by Flowers and Colmer (2008), halophytes are physiologically adapted to salinity stress, with some halophyte species having optimal growth rates under saline conditions and others under freshwater conditions. The zonation of halophyte species in a salt marsh reflects these differences in salt tolerance combined with tolerance to flooding (Rozema and Van Diggelen 1991). Higher tolerance to salt may co-occur with a lower tolerance to changes in nutrients, as shown for the halophyte Bolboschoenus maritimus compared with three freshwater species of Bolboschoenus, that may be attributed to evolutionary adaptation to salinity stress (Hroudová et al. 2014). For two other halophyte species, Salicornia europaea and Aster tripolium, it was shown that they can take up both organic and inorganic nitrogen (Quintã et al. $2015 \mathrm{a}, \mathrm{b}$ ), which is advantageous since salt marshes are often nitrogen-limited. This finding is interesting from the point of view of potential (organic) nutrient removal.

In order to compare nitrogen $(\mathrm{N})$ and phosphorus (P) removal efficiencies of three plant species originating from a tidal brackish marsh in the Netherlands, we conducted a pilot greenhouse experiment using two salinity levels, representative of the tidal brackish marsh, and one nutrient level. The species tested were $A$. tripolium, B. maritimus subsp. compactus, and Spartina anglica. Choice for these species was based on general presence in saline areas in Western Europe, differences in salt tolerance (Rozema and Van Diggelen 1991; Buhmann and Papenbrock 2013), and differences in hydrodynamic tolerance. The focus of our study was on the nutrient uptake in above- and belowground plant material at the end of the experiment, relevant for situations where biomass can be harvested, and on the nutrient removal from the inflowing water during the experiment, relevant for water purification. The ultimate aim of the experiment was to make a contribution to the full-scale applicability of saline constructed wetlands.

\section{Materials and methods}

The plant species

Aster tripolium is a biennial herbaceous plant, while $B$. maritimus subsp. compactus is a perennial graminoid herbaceous plant, and Spartina anglica is a perennial grass species. Spartina is commonly found in the transition zone from mud flat to salt marsh that is under tidal influence on a daily basis. It is relatively tolerant to prolonged inundation, e.g. at high tide. Compared to Spartina, Aster and Bolboschoenus are more typical of hydraulically less dynamic sites. They are common on Dutch salt marshes as well as in saline or brackish areas on the landward side of the dike.

\section{Collection of plants}

We collected A. tripolium, B. maritimus subsp. compactus and Spartina anglica on 26 April 2013 in 'Het Verdronken Land van Saeftinghe' (51 $34^{\circ}-\mathrm{N}, 4^{\circ} 18^{\prime}$ E), a saltmarsh reserve in the Scheldt estuary in the south-western Netherlands. In three sub-locations, each dominated by one of the three studied species, soil cores (diameter app. $20 \mathrm{~cm}$, depth app. $20 \mathrm{~cm}$ ) 
with living aboveground plant material were dug out using spades. For each species 24 cores were sampled, which was double the number needed in the experiment. The timing of the sampling was chosen to collect fresh sprouting plants, to study their performance during growth in the greenhouse. All sub-locations had brackish conditions and were situated in shallow depressions on the high inland end of the saltmarsh, with an average inundation frequency of approximately once or twice per month. Inundation is most frequent in the winter half-year. The sites where plant material was collected are grazed by cattle during the summer half-year (PepijnCalle, personal communication). The salinity of the Scheldt water varied between 10 and $20 \mathrm{PSU}$, and nutrient concentrations varied between 2 and $5 \mathrm{mg} \mathrm{N} / \mathrm{L}$, and $0.1-0.2 \mathrm{mg} \mathrm{P} / \mathrm{L}$.

The cores were put in $4 \mathrm{~L}$ plastic pots (diameter $18 \mathrm{~cm}$, height $15 \mathrm{~cm}$ ) and transported back to the greenhouse on the same day. Before putting the cores in the pots, the perforated bottoms of the pots were covered with a double layer of thinly perforated plastic foil to allow passage of effluent from the pots but minimise loss of soil material and roots growing out of the pots. To keep the soil cores moist during the acclimatization period, brackish surface water (salinity $10.8 \mathrm{PSU}, 16.4 \mathrm{mS} \mathrm{m}^{-1}$ ) was collected from two creeks near the sampling sites.

On 29 April 2013, standing dead litter from the previous growing season as well as other plant species present (notably Puccinellia sp.) were carefully removed from the soil cores. Each plastic pot was then placed in an individual metal pot lined with $40 \times 60 \mathrm{~cm}$ plastic bags to collect effluent from the soil cores. $300 \mathrm{ml}$ of the collected brackish ditch water was poured onto the soil cores of each pot. From 2 May 2013 onwards, a synthetic brackish solution (Coralsea, purchased from AquaHolland, Dordrecht, the Netherlands) was used for watering the pots during the remainder of the acclimatisation period $(1 / 3 \times$ sea water strength, corresponding to ditch water salinity in the sites where the plant material was collected).

\section{Experimental set-up}

After a 2 week acclimatisation period in the greenhouse, the experiment started on 8 May 2013. From the 24 available pots per species, we selected 12 pots where the plants had similar above ground biomass, similar total weight, similar number of sprouts, and had a healthy appearance. For each plant species we used two salinity levels and six replicate pots, resulting in 36 pots in total (three plant species $\times$ two salt concentrations $\times$ six replicates). The pots were placed on a large table in the greenhouse. For practical reasons, the experimental units were grouped according to salt concentration of the treatment solution. Within each of these salinity groups, the position of experimental units on the table in the greenhouse was randomised. To determine the plant conditions at the start of the experiment, of each plant species 4 additional pots were harvested to determine dry weight (DW) and nutrient concentration of shoots and roots at $\mathrm{t}=0$ (Supplemental Information, Table S-1). Climate conditions (light, temperature and relative humidity) in the greenhouse followed the natural fluctuations in Wageningen, as the greenhouse did not apply extra heating or light. Temperature and relative humidity $(\mathrm{RH})$ were recorded every $5 \mathrm{~min}$ during the whole experiment inside the greenhouse. Average daily temperature during the experiment ranged from 8.4 to $25.4{ }^{\circ} \mathrm{C}$ with a median value of $15.7^{\circ} \mathrm{C}$. Average daily $\mathrm{RH}$ ranged from 48.5 to $90.4 \%$ with a median value of $71.9 \%$.

All experimental units received the same nominal nutrient concentration of $15 \mathrm{mg} \mathrm{N} / \mathrm{L}$ and $2.5 \mathrm{mg} \mathrm{P} / \mathrm{L}$. This concentration was chosen to be representative for saline aquaculture effluents and agricultural runoff (see De Lange et al. 2013) and not much higher than the natural range of concentrations in the Scheldt estuary. Treatment solutions were made of the synthetic Coralsea water (AquaHolland) with Pokon universal plant nutrient solution (PokonNaturado BV, Veenendaal, the Netherlands) added to achieve the required concentration. By using Pokon the presence of trace elements was ensured $(\mathrm{K}, \mathrm{Fe}, \mathrm{Mn}, \mathrm{B}, \mathrm{Cu}, \mathrm{Zn}$, and Mo) (cf. Keizer-Vlek et al. 2014). Final pH of the used solution was $>8$, based on specifications of AquaHolland. Half of the experimental units received the nutrient solution at $1 / 10 \mathrm{x}$ sea water strength, the other half at $1 / 2 \times$ sea water strength, further referred to as low and high salinity. This reflects the range of salinities occurring at this part of the Scheldt Estuary. Treatment solutions were applied twice per week at a dose of $250 \mathrm{ml}$ per pot. The average salinity of the treatment solutions was 2.7 and 12.9 PSU for low and high salinity respectively.

Three weeks after the start of the experiment it was observed that some of the soil cores had become dry 
and hard with cracks in the clayey material mainly at the edges. After the second sampling point we applied extra rainwater to rewet the soil cores, including an additional weekly gift of $250 \mathrm{ml}$ rainwater. Visual inspection during the experiment did not indicate a significant or lasting impact of the soil drought on plant health or survival. This was confirmed by the data on effluent water, the fraction of water collected as effluent remained relatively constant during the first weeks, and plant height showed a gradual increase during the experiment (see Supplemental Information, Figs. S-1, S-2).

\section{Measurements}

Once per week, the volume of the effluent collected was measured and the plastic bags were emptied and clean bags re-installed beneath each experimental unit. During the experiment, plant height was measured, photos of the plants were made, and water samples from the effluent were taken four times at 2 week intervals. The water samples were filtered (Whatman $5951 / 2$ filter paper) and stored at $-20{ }^{\circ} \mathrm{C}$ prior to analysis. Concentrations of total dissolved $\mathrm{N}$ (NEN 6646 including internal extraction UV/persulfate) and total dissolved P (NEN6663 including internal extraction UV/persulfate) were determined using a Skalar SAN Plus continuous-flow analyser (Skalar Analytical BV, Breda, the Netherlands). Our focus in this pilot experiment was on the macronutrients $\mathrm{N}$ and $\mathrm{P}$, though we recognize the importance of other elements in osmoregulation processes and possible uptake competition between salt ions and nutrient ions (e.g. $\mathrm{Na}^{+}$reducing $\mathrm{K}^{+}$uptake or $\mathrm{Cl}^{-}$ reducing $\mathrm{NO}^{3-}$ uptake). Since we used two fixed salinity levels, differences in nutrient uptake can be considered as the net functioning of the three species, including competition between salts and nutrients.

The experiment was ended after 9 weeks by harvesting the aboveground biomass at the soil surface of the pots containing plants. This is further referred to as 'shoots', and included both stems and leaves. Belowground biomass was harvested by rinsing away the soil particles, this is further referred to as 'roots'. All harvested plant material was dried at $70{ }^{\circ} \mathrm{C}$ for at least $72 \mathrm{~h}$. After determining DW of the samples, the plant material was ground using ball mills and digested with $\mathrm{H}_{2} \mathrm{SO}_{4}$, salicylic acid, $\mathrm{H}_{2} \mathrm{O}_{2}$ and Se. Subsequently, the $\mathrm{N}$ and $\mathrm{P}$ concentrations of the diluted supernatant were determined using a Skalar SAN Plus continuous-flow analyser (Skalar Analytical BV, Breda, the Netherlands).

\section{Statistical analysis}

The experiment was designed to use a two-factor ANOVA to test for differences between treatments, with plant species and salt concentration as factors. Prior to analysis, the data were checked for normal distribution and homogeneity of variances. If necessary $\log (\mathrm{x}+1)$-transformation was applied to meet the ANOVA requirements. All statistical tests were done using Genstat 16th edition.

The ability of the plant-soil system to remove nutrients from inflowing water was calculated as concentration in the pouring solution minus the concentration in the effluent water, and referred to as delta $\mathrm{N}$ and delta P. Since this was measured four times during the experiment, the results were tested with a repeated measurements two-factor ANOVA. We expected this delta concentration to be positive due to plant uptake.

Dry weight (grams) and total $\mathrm{N}$ and $\mathrm{P}$ concentration (\% of DW) of the roots and shoots at $\mathrm{t}=0(\mathrm{n}=4$ per species) and $\mathrm{t}=$ end ( $\mathrm{n}=6$ per salt concentration per species) were combined to calculate the absolute uptake in grams of $\mathrm{N}$ and $\mathrm{P}$ in shoots and roots during the experiment. Relative growth rate $\left(\mathrm{RGR}, \mathrm{d}^{-1}\right)$ of the plants was calculated as $(\ln ($ final $D W)-\ln$ (initial DW))/(time in days), using the shoot DW (cf. Brown et al. 1999).

Data on $\mathrm{N}$ and $\mathrm{P}$ content in shoots and roots did not meet the conditions of homogeneity of variances and normal distribution of error terms, not even after logtransformation. Therefore we tested differences between treatments using the non-parametric Kruskal-Wallis test, followed by pair-wise comparisons using Mann-Whitney U tests.

\section{Results and discussion}

Net nutrient removal: comparing concentrations in effluent water and in pouring solution

Delta $\mathrm{N}$ concentration differed between species ( $\mathrm{p}=0.003$ ) with Spartina having significantly higher delta $\mathrm{N}$ than Aster (Fig. 1). There also was a 
significant time effect $(\mathrm{p}=0.041)$, with the third sampling timepoint having significantly higher delta $\mathrm{N}$ than the first sampling timepoint. Finally, the high salinity pots had more variety in delta $\mathrm{N}$ at the different sampling points than the low salinity pots, resulting in significant time $\times$ salt interaction effect $(\mathrm{p}=0.002)$ (Fig. 1). Delta $\mathrm{P}$ concentration also differed between species $(\mathrm{p}=<0.001)$ with Spartina and Bolboschoenus having significantly higher delta $\mathrm{P}$ than Aster. Again, there was a significant time effect ( $\mathrm{p}<0.001$ ), with significantly increasing delta $\mathrm{P}$ for the first three sampling timepoints (Fig. 1). There was no significant effect of salt concentration on delta $\mathrm{P}$.

For some samples, mostly in the low salinity treatment, the concentration of total $\mathrm{N}$ in the effluent water was higher than in the pouring water, resulting in a negative delta (see also Supplemental Information, fig. S-3). This might be caused by a complex of

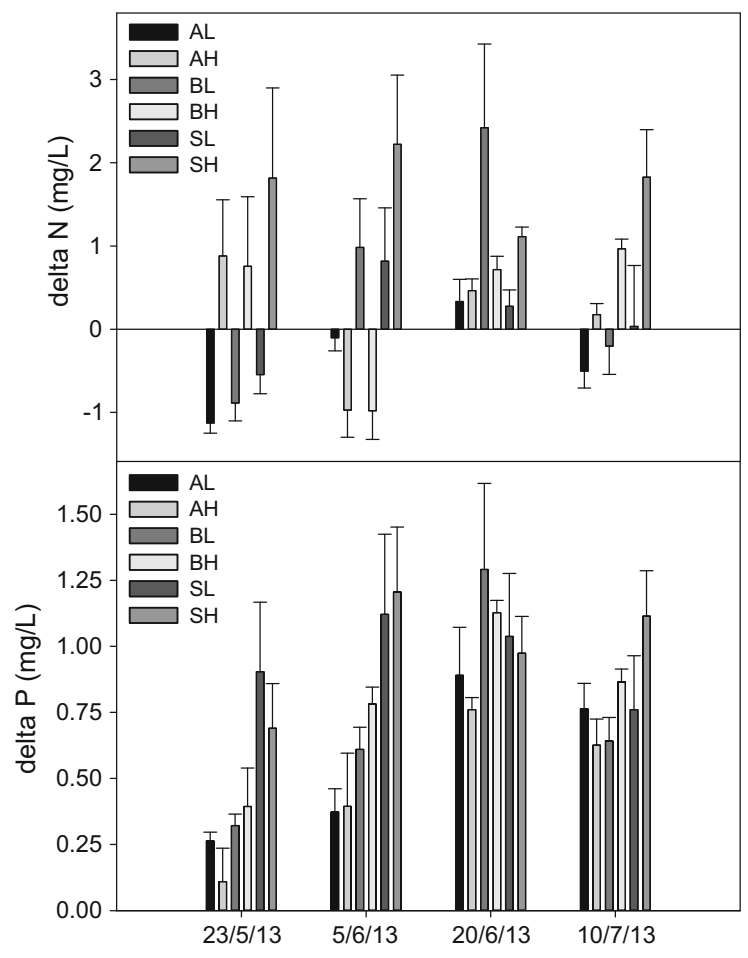

Fig. 1 Delta total dissolved $\mathrm{N}$ concentration (upper panel) and delta total dissolved $\mathrm{P}$ concentration (lower panel) at the four sampling points in time, calculated as concentration in inflow minus percolated water, average $\pm 1 \mathrm{SE}(\mathrm{n}=6)$. Treatments are abbreviated as follows: AL Aster low salinity, AH Aster high salinity, BL Bolboschoenus low salinity, BH Bolboschoenus high salinity, SL Spartina low salinity, SH Spartina high salinity. Positive values indicate net uptake in the pots processes in the soil core causing net $\mathrm{N}$ release. This happened mostly during the first weeks of the experiment, during the second half of the experiment the plant-soil system retained more nitrogen. For total $\mathrm{P}$, the delta concentration was positive for most replicate pots, indicating that the $\mathrm{P}$ is mostly retained in the plant and soil system (Fig. 1). Also, delta $\mathrm{P}$ is more stable than delta $\mathrm{N}$ during the experiment. The important difference between $\mathrm{N}$ and $\mathrm{P}$ behaviour in the plant-soil system is that $\mathrm{N}$ is more mobile and is subject to various microbial processes which makes it more prone to variation, whereas the behaviour of $\mathrm{P}$ is more governed by physico-chemical processes such as absorption to clay particles (Kadlec and Wallace 2009). The significant time effect for both delta $\mathrm{N}$ and delta $\mathrm{P}$ indicates that the plant-soil system needed to adapt to a new nutrient uptake equilibrium, which is in agreement with results of Lymbery et al. (2013). It also reflects that during the exponential growth phase, uptake of nutrients increased (see Supplemental Information Fig. S-4 for increase in plant height during the experiment). Based on these results, we expect that given a longer time period, delta $\mathrm{N}$ would become more stable as well, but with more fluctuations than delta $\mathrm{P}$ because of the microbial processes of $\mathrm{N}$. However, given the pilot nature of our experimental setup, this should be further tested in more detailed experiments.

Delta $\mathrm{N}$ ranged from -1 to $2 \mathrm{mg} \mathrm{N} / \mathrm{L}$ (Fig. 1), which corresponds to a maximal removal efficiency of $11 \%$. This is low compared with results from other greenhouse or microcosm studies testing different salttolerant species. These studies report removal efficiencies of around $70 \%$ for $\mathrm{NH}_{3}-\mathrm{N}$ (Klomjek and Nitisoravut 2005) or $>95 \%$ for total $\mathrm{N}$ (Brown et al. 1999). At pilot-scale constructed wetland cells, removal efficiencies for total nitrogen are reported to be $98 \%$ (Webb et al. 2012) and around $70 \%$ (Lymbery et al. 2013).

Delta $\mathrm{P}$ ranged from 0.1 to $1.3 \mathrm{mg} \mathrm{P} / \mathrm{L}$ (Fig. 1), which corresponds to a maximal removal efficiency of $35 \%$. This is in the same range as reported by Klomjek and Nitisoravut (2005) and Webb et al. (2012), but lower than reported by Brown et al. (1999), Lymbery et al. (2006) and Lymbery et al. (2013) who report removal efficiencies of $>95 \%$, around $50 \%$, and around $80 \%$ respectively.

Both Brown et al. (1999), Klomjek and Nitisoravut (2005) and Lymbery et al. (2013) report similar high 
removal efficiencies in the soil of control pots or in the unplanted wetland cells for both total $\mathrm{N}$ and total $\mathrm{P}$, indicating that most of the removal action takes places in the soil core, and not by the plant. To better understand the processes responsible for nutrient removal and/or storage and their respective share in removal, microbial processes in the soil deserve further attention in follow-up experiments. Our pilot experiment only gives a first indication on the net outcome of these plant-soil processes.

Nutrient uptake in plant shoots and roots

Above-and belowground biomass was harvested at the end of the experiment. The average shoot DW was not significantly different between species or salinity level, and was $20.0 \pm 6.2,18.5 \pm 4.0$ and $19.0 \pm$ $6.2 \mathrm{~g}$ (average $\pm 1 \mathrm{SD}$ ) for Aster, Bolboschoenus and Spartina respectively. This absence of salinity effect on shoots was also found by Lymbery et al. (2013). However, in our experiment the RGR differed significantly between species ( $p<0.001)$, but not between salt levels nor was there a significant interaction effect. RGR based on shoot DW was on average $0.026 \pm 0.005,0.042 \pm 0.003$, and $0.034 \pm 0.005$ $\mathrm{d}^{-1}$ (average $\pm 1 \mathrm{SD}$ ) for Aster, Bolboschoenus and Spartina respectively. This range of values was similar as reported by Brown et al. (1999), and higher than the values reported by Klomjek and Nitisoravut (2005). This supports that the conditions in our experiment were sufficient for healthy plant growth.

Root DW differed significantly between species ( $\mathrm{p}<0.001$ ), but not between salt levels nor was there a significant interaction. Average root DW of Aster was significantly lower $(58 \pm 24 \mathrm{~g})$ than of Bolboschoenus and Spartina (104 \pm 45 and $119 \pm 48 \mathrm{~g}$, respectively, average $\pm 1 \mathrm{SD}$ ) (ANOVA $\mathrm{p}<0.001$ ).

At the end of the experiment, $\mathrm{N}$ concentration in shoots was highest in Aster and Bolboschoenus, while $\mathrm{N}$ concentration in roots was highest in Aster and Spartina (Kruskal-Wallis followed by Mann-Whitney $\mathrm{U}$ tests $\mathrm{p}<0.05$; Fig. 2). The $\mathrm{N}$ concentration in Aster shoots was slightly lower, and the concentration in Aster roots was much lower than reported values by Quintã et al. (2015b). This difference may be because our plants were larger and presumably in a different growth phase: $20 \mathrm{~g} \mathrm{DW}$ in our experiment compared with $0.5-1.0$ g DW reported by Quintã et al. (2015b), who grew their plants from seeds. $\mathrm{P}$ concentration in shoots was highest in Aster and lowest in Spartina, while $\mathrm{P}$ concentration in roots was highest in Bolboschoenus and lowest in Spartina (Kruskal-Wallis followed by Mann-Whitney U tests $\mathrm{p}<0.05$; Fig. 2). The nutrient concentration ratio between shoots and roots shows that $\mathrm{N}$ was more stored in the shoots, most strongly for Bolboschoenus (ratio $>1$ ) whereas $\mathrm{P}$ was more stored in the roots, most strongly for $\mathrm{Bol}$ boschoenus and Spartina (ratio < 1) (Kruskal-Wallis followed by Mann-Whitney U tests $\mathrm{p}<0.05$; Fig. 2). Salinity level had no significant effect on the nutrient concentration in roots and shoots (Kruskal-Wallis, $\mathrm{p}>0.05)$.

The absolute uptake of nutrients during the experiment in plant shoots and roots was calculated using DWs and $\mathrm{N}$ and $\mathrm{P}$ concentration at start and end of the experiment (Fig. 3). Bolboschoenus had significantly higher shoot $\mathrm{N}$ uptake than Aster, with Spartina having intermediate values. There was no significant overall effect of salinity level. Bolboschoenus had significantly higher shoot $\mathrm{P}$ uptake than Spartina, with Aster having intermediate values. Again there was no significant overall effect of salinity level (Fig. 3), although Bolboschoenus had higher nutrient uptake in shoots at low salt concentrations ( $t$ test, $\mathrm{p}=0.055$ and $\mathrm{p}=0.002$ for $\mathrm{N}$ and $\mathrm{P}$ respectively).

$\mathrm{N}$ and $\mathrm{P}$ uptake in roots differed significantly between species, without a salinity effect, and was highest in Spartina and lowest in Aster (Fig. 3). In general, root DW was higher than shoot DW, and this resulted in a higher total amount of nutrients in roots compared with shoots. However, since in full-scale saline treatment wetlands aboveground biomass can be harvested more easily than belowground biomass, uptake of nutrients in shoots is more relevant when comparing performance of species for such cases.

\section{Upscaling from pilot experiments}

Although our experiment is on a pilot scale, the results of our experiment can be used in choosing the optimal plant species to test further for use in a saline constructed wetland. This choice depends on purpose and management options, salinity conditions and hydraulic regime. Some first conclusions can be drawn from our pilot experiments, but further upscaling experiments are needed to support our results when applied to field scale. If the focus is on nutrient 


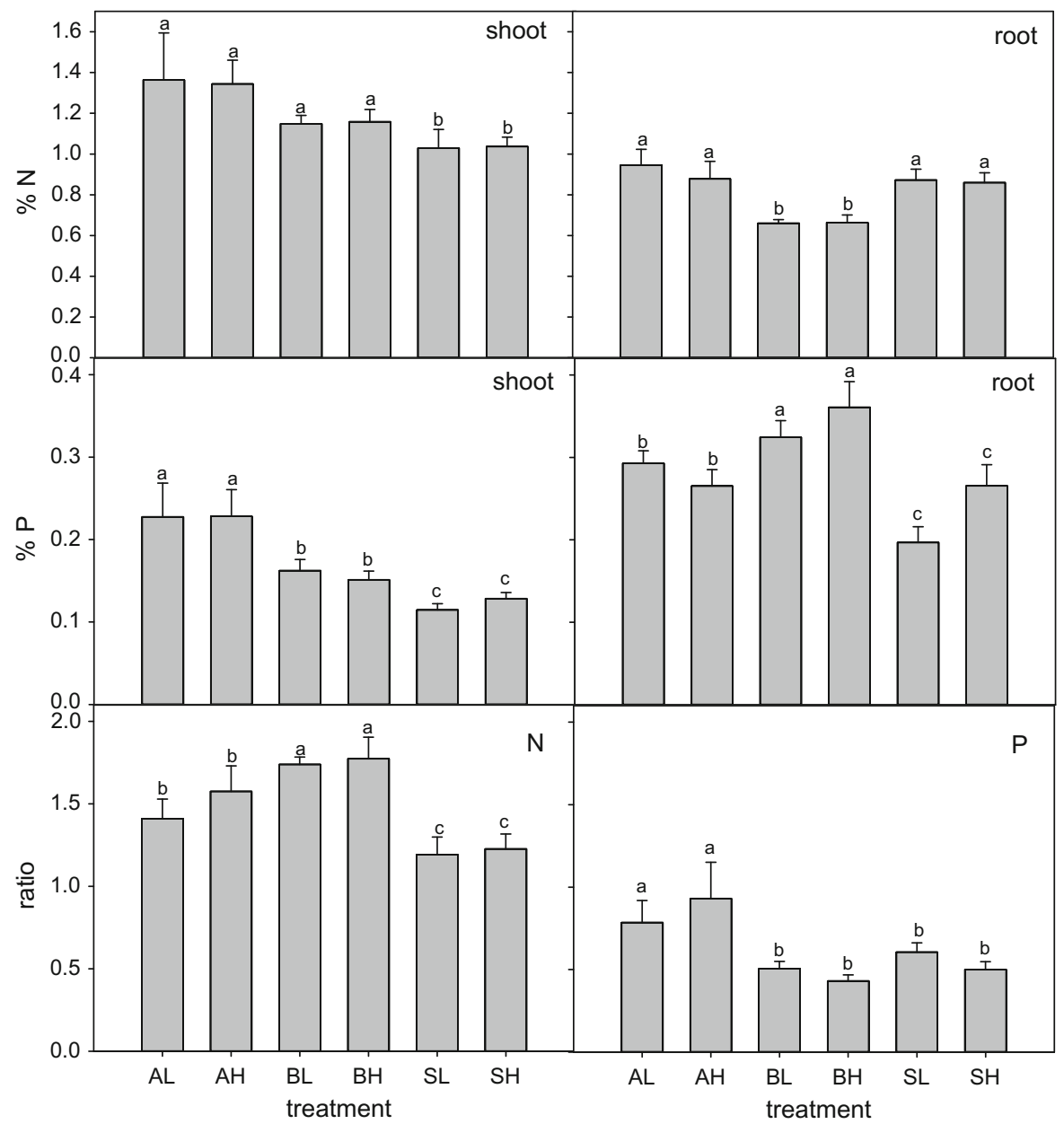

Fig. $2 \mathrm{~N}$ concentration (upper panels) and $\mathrm{P}$ concentration (middle panels) for shoots (left panels) and roots (right panels), and shoot/root ratio of $\mathrm{N}$ and $\mathrm{P}$ (lower panels); average $\pm 1 \mathrm{SE}$

removal from water, Spartina and Bolboschoenus achieve higher removal rates than Aster. If aboveground biomass can be harvested, Bolboschoenus has the advantage of the highest uptake rates for both $\mathrm{N}$ and $\mathrm{P}$ in aboveground biomass. This biomass could be used for other purposes, e.g. generating energy from biomass. However, the economic gain of this is still difficult to achieve (Meerburg et al. 2010). There was a limited effect of salinity. This might indicate that the two tested salinity levels are in the natural range of the three species. It was not our purpose to investigate the optimal salinity for each species, but for this pilot experiment we simply chose two salinities representative for the Western Scheldt estuary. Within this salinity range tested, Aster performed better under the $(n=6)$. Letters indicate homogeneous groups (Kruskal-Wallis followed by Mann-Whitney $U$ tests $\mathrm{p}<0.05)$. Treatment abbreviations as in Fig. 1

high salinity conditions, so if the location or the effluent to be treated is more saline, Aster can be a good choice. Bolboschoenus and Spartina are comparable in removing nutrients from the water, and nutrient storage in the shoots. Spartina tolerates fluctuations in water level better than Bolboschoenus, so Spartina may be a good choice for lower-lying locations with large water level fluctuations.

The initial choice for these three species was made based on natural common occurrence in western Europe. The performance in the pilot experiment is promising enough to conduct further experiments with these three species, to investigate how the species will perform in terms of nutrient uptake and retention, and efficiency per unit area. Depending on the ecoregion, 


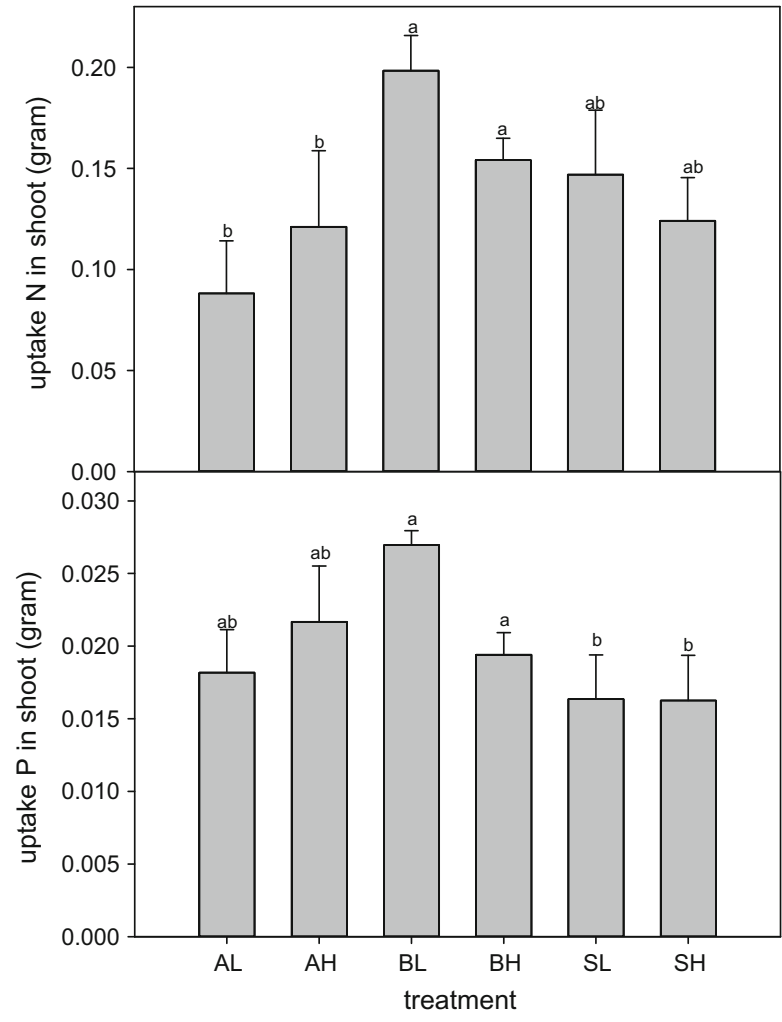

Fig. 3 Uptake of $\mathrm{N}$ (upper panels) and $\mathrm{P}$ (lower panels) in aboveground plant biomass (left side panels) and belowground biomass (right side panels), average $\pm 1 \mathrm{SE}(\mathrm{n}=6)$. Letters

the search for better-performing could be extended to other species as well.

\section{Conclusions}

The main aim of this experiment was to compare different halophyte species of common occurrence in temperate Europe on nutrient removal in treatment water and nutrient uptake in plant biomass. Although our experiment treated the soil processes as a black box, the results show several outcomes that can be used in the future. The observed RGR of the three species showed that the experimental conditions were sufficiently good to support our conclusions. Nutrient removal from water differed between species: Spartina had the highest $\mathrm{N}$ removal, Bolboschoenus and Spartina had the highest $\mathrm{P}$ removal. Bolboschoenus had the highest absolute uptake of $\mathrm{N}$ and $\mathrm{P}$ in shoots, whereas Spartina had the highest uptake of $\mathrm{N}$ and $\mathrm{P}$ in

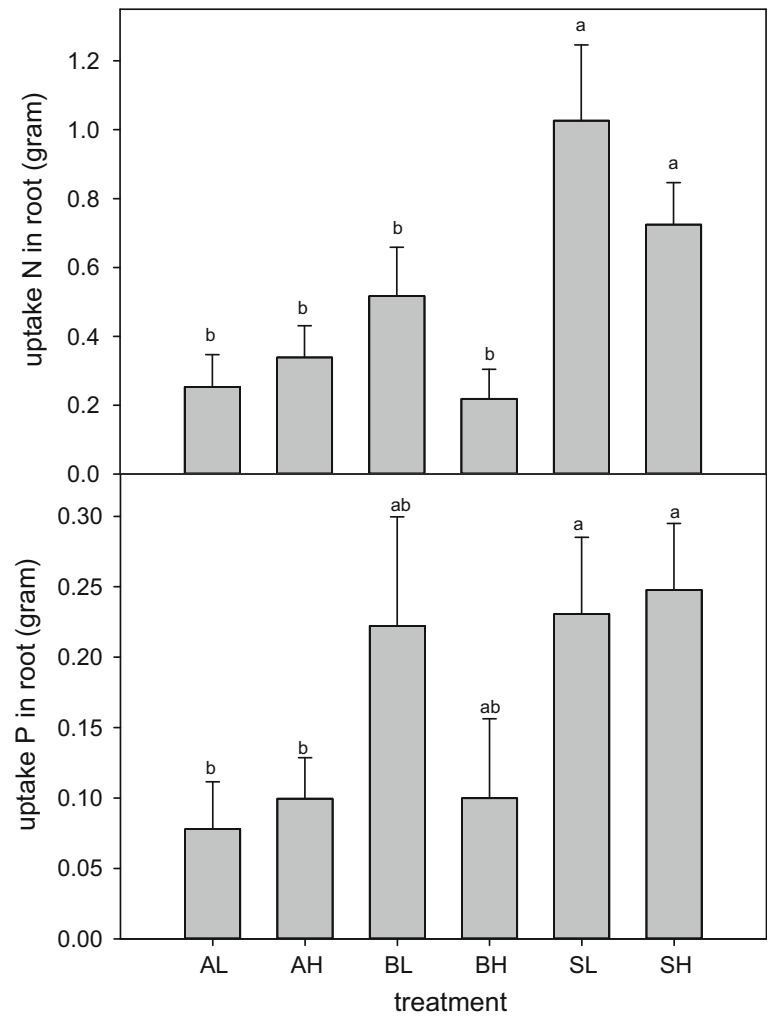

indicate homogeneous groups (ANOVA followed by post hoc LSD test). Treatment abbreviations as in Fig. 1

roots. Salinity of the treatment water was not a significant factor, except for nutrient uptake in Bolboschoenus which was higher at low salinity. These results can be used in choosing the optimal plant species for use in a saline constructed wetland. This choice depends on site-specific characteristics and purpose of the constructed wetland, such as management type, salinity conditions and hydraulic regime.

Acknowledgments We thank Chiel Jacobusse of Stichting Het Zeeuwse Landschap for his help in obtaining permission to collect the plant material in the saltmarsh reserve. Pepijn Calle (Stichting Het Zeeuwse Landschap) kindly helped during fieldwork and provided information about the characteristics of the plant collection sites. We also thank Rinie Verwoert, Jolanda Bierman, Wim Lieftink and others at Unifarm (Wageningen University and Research Centre) for their advice and assistance before and during the experiment. Sija Stofberg (Wageningen University) assisted during the experiment and harvest. Jan van Walsem and Frits Gillissen (Wageningen University) carried out the nutrient analyses. We thank Monique Heijmans (Wageningen University) for constructive comments on an earlier version of the manuscript. Comments of two 
anonymous reviewers further improved the manuscript. The experiment was financed by the Dutch Ministry of Economic Affairs through the Kennisbasis programme (Project No. KB14-005-034).

Open Access This article is distributed under the terms of the Creative Commons Attribution 4.0 International License (http:// creativecommons.org/licenses/by/4.0/), which permits unrestricted use, distribution, and reproduction in any medium, provided you give appropriate credit to the original author(s) and the source, provide a link to the Creative Commons license, and indicate if changes were made.

\section{References}

Brown JJ, Glenn EP, Fitzsimmons KM, Smith SE (1999) Halophytes for the treatment of saline aquaculture effluent. Aquaculture 175(3-4):255-268. doi:10.1016/S00448486(99)00084-8

Buhmann A, Papenbrock J (2013) Biofiltering of aquaculture effluents by halophytic plants: basic principles, current uses and future perspectives. Environ Exp Bot 92:122-133. doi:10.1016/j.envexpbot.2012.07.005

Calheiros CSC, Quitério PVB, Silva G, Crispim LFC, Brix H, Moura SC, Castro PML (2012) Use of constructed wetland systems with Arundo and Sarcocornia for polishing high salinity tannery wastewater. J Environ Manag 95:66-71. doi:10.1016/j.jenvman.2011.10.003

Carvalho F, Prazeres AR, Rivas J (2013) Cheese whey wastewater: characterization and treatment. Sci Total Environ 445:385-396. doi:10.1016/j.scitotenv.2012.12.038

De Lange HJ, Paulissen MPCP, Slim PA (2013) Halophyte filters: the potential of constructed wetlands for application in saline aquaculture. Int $\mathrm{J}$ Phytoremediat 15:352-364. doi:10.1080/15226514.2012.702804

Flowers TJ, Colmer TD (2008) Salinity tolerance in halophytes. New Phytol 179(4):945-963

Gautier D, Amador J, Newmark F (2001) The use of mangrove wetland as a biofilter to treat shrimp pond effluents: preliminary results of an experiment on the Caribbean coast of Colombia. Aquacult Res 32(10):787-799. doi:10.1046/j. 1365-2109.2001.00614.x

Gennaro P, Guidotti M, Funari E, Porrello S, Lenzi M (2006) Reduction of land based fish-farming impact by phytotreatment pond system in a marginal lagoon area. Aquaculture 256(1-4):246-254. doi:10.1016/j. aquaculture.2006.02.028

González-Alcaraz MN, Conesa HM, Álvarez-Rogel J (2013) Phytomanagement of strongly acidic, saline eutrophic wetlands polluted by mine wastes: the influence of liming and Sarcocornia fruticosa on metals mobility. Chemosphere 90:2512-2519. doi:10.1016/j.chemosphere.2012.10.083

Gregory SP, Shields RJ, Fletcher DJ, Gatland P, Dyson PJ (2010) Bacterial community responses to increasing ammonia concentrations in model recirculating vertical flow saline biofilters. Ecol Eng 36:1485-1491. doi:10. 1016/j.ecoleng.2010.06.031
Gregory SP, Dyson PJ, Fletcher D, Gatland P, Shields RJ (2012) Nitrogen removal and changes to microbial communities in model flood/drain and submerged biofilters treating aquaculture wastewater. Aquacult Eng 50:37-45. doi:10.1016/j. aquaeng.2012.03.006

Hroudová Z, Zákravský P, Flegrová M (2014) The tolerance to salinity and nutrient supply in four European Bolboschoenus species (B. maritimus, B. laticarpus, B. planiculmis and B. yagara) affects their vulnerability or expansiveness. Aquat Bot 112:66-75

Jesus JM, Calheiros CSC, Castro PML, Borges MT (2014) Feasibility of Typha latifolia for high salinity effluent treatment in constructed wetlands for integration in resource management systems. Int $\mathrm{J}$ Phytoremediat 16(4):334-346. doi:10.1080/15226514.2013.773284

Kadlec RH, Wallace SD (2009) Treatment wetlands, 2nd edn. CRC Press, Boca Raton

Kanagy LE, Johnson BM, Castle JW, Rodgers JH Jr (2008) Design and performance of a pilot-scale constructed wetland treatment system for natural gas storage produced water. Bioresour Technol 99:1877-1885. doi:10.1016/j. biortech.2007.03.059

Keizer-Vlek HE, Verdonschot PFM, Verdonschot RCM, Dekkers D (2014) The contribution of plant uptake to nutrient removal by floating treatment wetlands. Ecol Eng 73:684-690. doi:10.1016/j.ecoleng.2014.09.081

Klomjek P, Nitisoravut S (2005) Constructed treatment wetland: a study of eight plant species under saline conditions. Chemosphere 58(5):585-593. doi:10.1016/j.chemosphere. 2004.08.073

Laegdsgaard P (2006) Ecology, disturbance and restoration of coastal saltmarsh in Australia: a review. Wetl Ecol Manag 14(5):379-399

Lin YF, Jing SR, Lee DY, Chang YF, Sui HY (2010) Constructed wetlands for water pollution management of aquaculture farms conducting earthen pond culture. Water Environ Res 82(8):759-768. doi:10.2175/106143010X12 609736966685

Lymbery AJ, Doupé RG, Bennett T, Starcevich MR (2006) Efficacy of a subsurface-flow wetland using the estuarine sedge Juncus kraussii to treat effluent from inland saline aquaculture. Aquacult Eng 34:1-7. doi:10.1016/j.aquaeng. 2005.03.004

Lymbery AJ, Kay GD, Doupé RG, Partridge GJ, Norman HC (2013) The potential of a salt-tolerant plant (Distichlisspicata cv. NyPa Forage) to treat effluent from inland saline aquaculture and provide livestock feed on salt-affected farmland. Sci Total Environ 445:192-201

Meerburg B, Vereijken P, de Visser W, Verhagen J, Korevaar H, Querner E, de Blaeij A, van der Werf A (2010) Surface water sanitation and biomass production in a large constructed wetland in the Netherlands. Wetl Ecol Manag 18(4):463-470. doi:10.1007/s11273-010-9179-x

Quintã R, Hill PW, Jones DL, Santos R, Thomas DN, LeVay L (2015a) Uptake of an amino acid (alanine) and its peptide (trialanine) by the saltmarsh halophytes Salicornia europaea and Aster tripolium and its potential role in ecosystem $\mathrm{N}$ cycling and marine aquaculture wastewater treatment. Ecol Eng 75:145-154

Quintã R, Santos R, Thomas DN, le Vay L (2015b) Growth and nitrogen uptake by Salicornia europaea and Aster 
tripolium in nutrient conditions typical of aquaculture wastewater. Chemosphere 120:414-421

Roncken PA, Stremke S, Paulissen MPCP (2011) Landscape machines: productive nature and the future sublime. J Landscape Archit (spring): 68-81. http://edepot.wur.nl/ 195288

Rozema J, Flowers T (2008) Crops for a salinized world. Science 322(5907):1478-1480. doi:10.1126/science. 1168572

Rozema J, Van Diggelen J (1991) A comparative study of growth and photosynthesis of four halophytes in response to salinity. Acta Oecol 12(5):673-681

Shpigel M, Ben-Ezra D, Shauli L, Sagi M, Ventura Y, Samocha T, Lee JJ (2013) Constructed wetland with Salicornia as a biofilter for mariculture effluents. Aquaculture 412-413: 52-63. doi:10.1016/j.aquaculture.2013.06.038

Tao R, Yu KW (2013) Nitrate addition has minimal effect on anaerobic biodegradation of benzene in coastal saline (salt), brackish and freshwater marsh sediments. Wetlands 33(4):759-767. doi:10.1007/s13157-013-0435-8

Tilley DR, Badrinarayanan H, Rosati R, Son J (2002) Constructed wetlands as recirculation filters in large-scale shrimp aquaculture. Aquacult Eng 26(2):81-109. doi:10. 1016/S0144-8609(02)00010-9

Verhoeven JTA, Meuleman AFM (1999) Wetlands for wastewater treatment: opportunities and limitations. Ecol Eng 12:5-12. doi:10.1016/S0925-8574(98)00050-0

Webb JM, Quintã R, Papadimitriou S, Norman L, Rigby M, Thomas DN, Le Vay L (2012) Halophyte filter beds for treatment of saline wastewater from aquaculture. Water Res 46:5102-5114. doi:10.1016/j.watres.2012.06.034

Webb JM, Quintã R, Papadimitriou S, Norman L, Rigby M, Thomas DN, le Vay L (2013) The effect of halophyte planting density on the efficiency of constructed wetlands for the treatment of wastewater from marine aquaculture. Ecol Eng 61:145-153. doi:10.1016/j.ecoleng.2013.09.058

Ye Y, Tam NFY, Wong YS (2001) Livestock wastewater treatment by a mangrove pot-cultivation system and the effect of salinity on the nutrient removal efficiency. Mar Pollut Bull 42(6):513-521. doi:10.1016/S0025-326X(00)00196-X 